\title{
Bone Morphogenetic Protein の多機能性と内分泌調節
}

\author{
大塚文男
}

岡山大学大学院医歯薬学総合研究科 総合内科学

キーワード：骨形成蛋白, BMP, 成長因子, 内分泌

\section{Multifunctional BMP and its endocrine regulation}

\section{Fumio Otsuka}

Department of General Medicine, Okayama University Graduate School of Medicine, Dentistry and Pharmaceutical Sciences

\section{はじめに}

我々はこれまで，骨形成蛋白（bone morphogenetic protein：BMP) の作用や生理的意義について, 卵巣・ 下垂体・副腎 - 骨 - 甲状腺・乳腺などの内分泌腺を中 心に探索してきた（以下のレビュー論文を参照 ${ }^{1-9)}$ ). BMP は, TGF- $\beta$, inhibin/activin, Vg1, ミューラー 管抑制因子 $(\mathrm{MIS} / \mathrm{AMH})$ などを含む $\mathrm{TGF}-\beta$ スーパー ファミリーに属し, 初期胚の器官形成や中胚葉誘導に 重要な役割を果たしている。元来 BMP は骨化を促す 物質として1965年にUristらにより発見された。その 後, 1988年の Wozney らによる BMP- 2, - 3, - 4 のク ローニングに続き BMP- $5,-6,-7$ が同定され, 1998 年には異なる 2 つの研究室から growth differentiation factor (GDF)- 9 と高い相同性をもつ BMP-15(GDF-9B) がクローニングされた。

30 種以上からなる BMP 分子群は, TGF- $\beta$ スーパー ファミリーのなかで最も大きいサブグループである. なかでも BMP-15はX染色体にコードされ, 卵巣の卵

\section{平成 25 年 5 月受理}

厂700-8558 岡山市北区鹿田町 2-5-1

電話：086-235-7342 FAX : 086-235-7345

E-mail : fumiotsu@md.okayama-u.ac.jp
母細胞に特異的に発現していることが分かり，我々は まず卵胞における BMP-15の機能解析から着手した。 このBMP-15の卵巣における研究の過程で, BMP が 骨のみならず種々の内分泌組織において autocrine/ paracrine 機序で組織特有の作用を発揮することが明 らかとなった。 以下, 我々が研究を進めてきた卵巣・ 下垂体・副腎を中心に，BMPによる多様な生理活性 と作用メカニズム，その応用性について述べる。

\section{卵巣 BMP システムによる卵胞成長の支持作用}

骨化を促す蛋白として命名された BMP は, 胚発生 と中胚葉分化に必要な分子群でもあり, BMP リガン ドや受容体サブタイプのノックアウトマウスの多くは 胎生致死となる。そのため BMP の生殖内分泌機能に 関する探求は当初困難であった。我々は，まず卵母細 胞特異的に発現する活性型 BMP-15蛋白を作成した。 ラット顆粒膜細胞の初代培養を用いた検討によって, BMP-15が卵胞刺激ホルモン（FSH）受容体の発現を 抑制して黄体ホルモン（progesterone：P 4) の合成を 制御すること, 卵母細胞との細胞間コミュニケーショ ンを介して顆粒膜細胞の増殖に寄与すること，そして BMP-15の受容体がALK-6/BMPRII であり細胞内 シグナルとして Smad1/ $5 / 8$ 経路を活性化することを

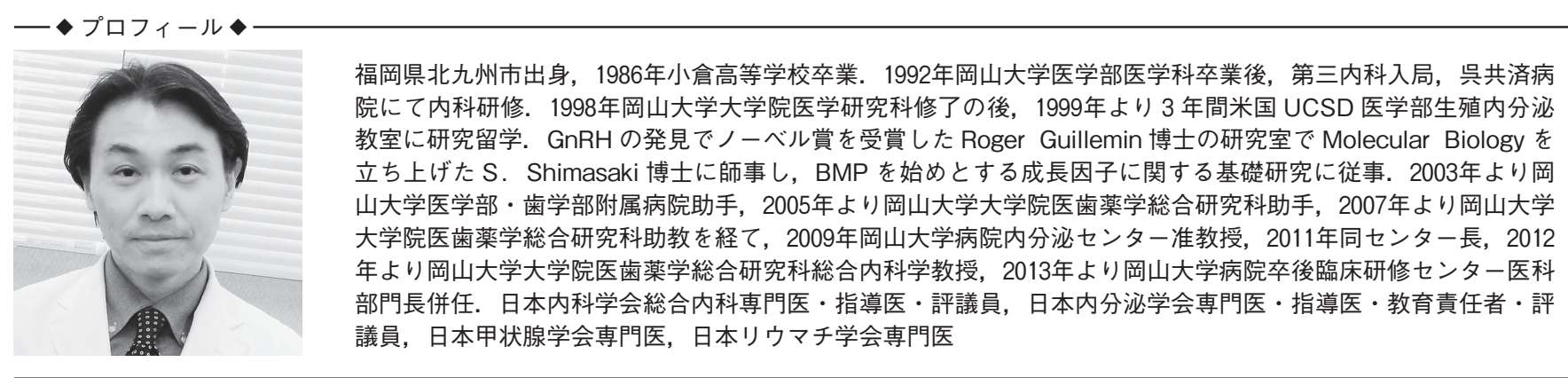


見出した.さらに卵母細胞由来の BMP-15が homodimer としてのみならず分子相同性の高い $\mathrm{GDF}-9$ と heterodimer を形成することを証明した ${ }^{1-3)}$.

我々の BMP-15の研究に先立ち, BMP-15 と同様に 卵母細胞特異的な発現が認められる GDF-9について は, 米国べイラー医科大学の Dr. Matzukらにより精 力的な研究が行われ, GDF-9 欠損マウスで卵胞発育 が早期から中断することが証明されていた。一方，二 ユージーランドの研究グループは自然発症的に卵巣不 全を生ずるヒッジ(FecXI, FecXH)において, BMP-15 成熟蛋白に変異の存在を発見し, ホモ体変異で不妊・ ヘテロ体で多産という BMP-15の多寡による特異的 な生殖表現型に関与することを明らかにした。その後， BMP-15受容体である BMP 1 型受容体 $(A L K-6)$ の 遺伝子変異が, 多産のヒッジ ( FecB) の成因であるこ とも発見され, BMP-15関連遺伝子の変異ヒッジの形 質と我々の生理活性デー夕を統合することで, BMP-15 の生殖内分泌における重要性が浮き彫りとなった。さ らに2004年に報告された卵巣不全のイタリア人姉妹を 皮切りに, ヒトに拈りる BMP-15変異や遺伝子多型に よる生殖機能の異常が各国より報告され，この分子の 卵巣機能調節における意義が一層明確となった。興味 深いことに，ヒトとマウスでは BMP-15プロ蛋白から 成熟蛋白へのプロセッシング機構や分泌機序に相違が
あり，BMP-15は特にヒトやヒツジなどの少排卵動物 の生殖に必須で, 排卵数の種差にも関連していること が暗示された ${ }^{6,7)}$.

卵母細胞由来の BMP-15をはじめ，卵胞に発現する BMP リガンド $(\mathrm{BMP}-2,-4,-6,-7,-15, \mathrm{GDF}-$ 9 など) は共通して FSH の刺激下で卵胞顆粒膜細胞に よる P 4 産生を抑制する作用をもつことから，正常な 卵巣では未成熟な排卵を抑制する黄体化抑制因子 (luteinizing inhibitor) として作動していると考えら れる（図 1)。一方で, estradiol（E2）産生に対して はリガンドにより異なる作用をもつ. BMP- 6, -15は 直接 $\mathrm{E} 2$ 産生には影響しないが, $\mathrm{BMP}-2,-4,-7$ は FSH 受容体シグナル下流の MAPK を調節してE 2 産 生を促し，この系は卵母細胞の存在で増幅される。 BMP-15と同じく卵から分泌される fibroblast growth factor $(\mathrm{FGF})-8$ も MAPK を介してE 2 抑制に寄与し ており，顆粒膜細胞の増殖に必須の kit ligand (KL)/ c-kitループが卵から FGF- 8 を介して E 2 合成を抑制 する。ささらに顆粒膜細胞での KL 発現は BMP-15によ り促進される。つまり，図 1 に示すように卵胞の BMP 分子群は，構成する卵母細胞・顆粒膜細胞・萊膜細胞 の間で機能的ネットワークを形成し，卵胞発育や卵巣 ステロイド合成を巧みに調節していると考えられる ${ }^{7,9)}$.

内分泌の病態における場面では，この卵胞 BMP シ

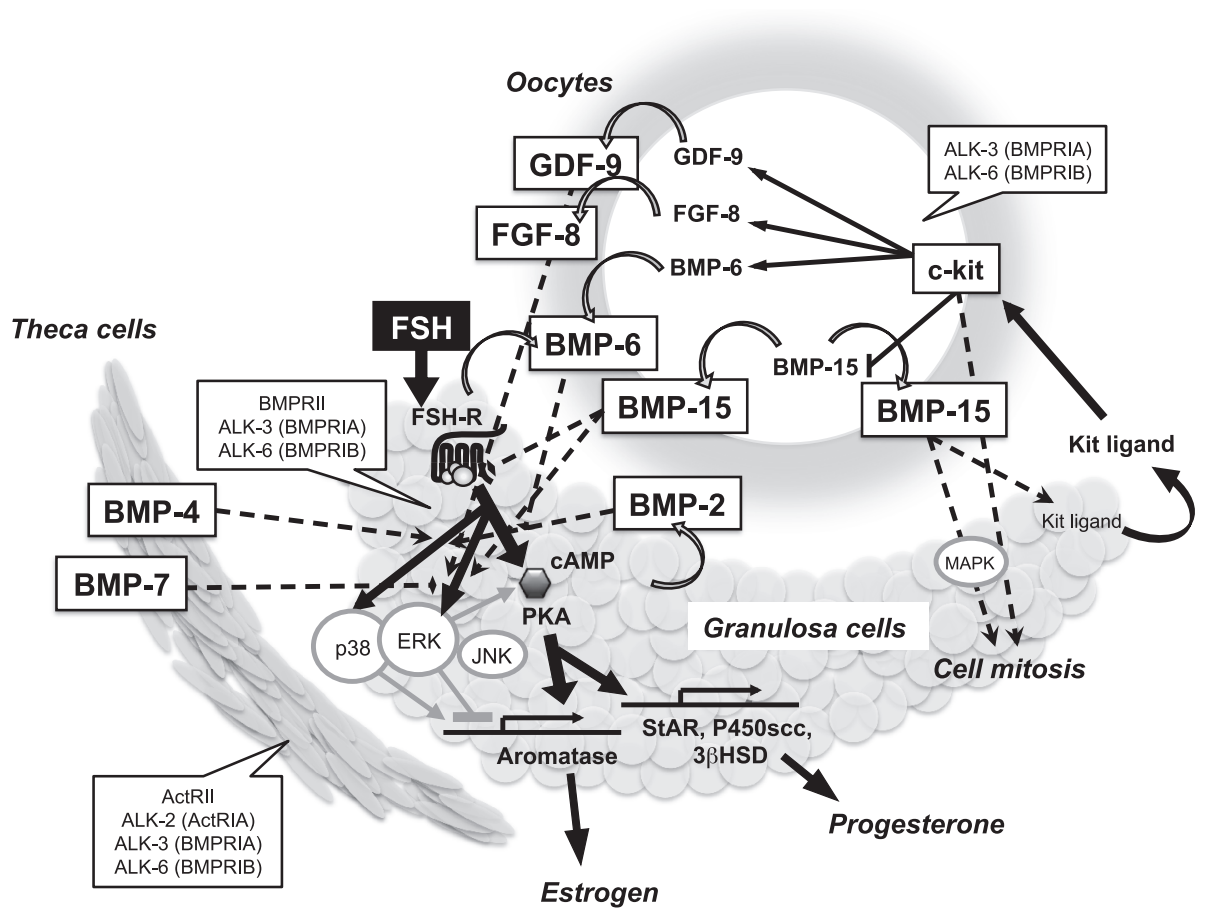

図 1 卵巣顆粒膜細胞の機能調節に寄与する BMP 
ステムが生殖機能への影響を緩和する因子として作動 するようである。例えば，高プロラクチン（PRL）状 態に晒された卵胞では, 早期の P 4 増加により未成熟 な排卵を生ずる可能性があるが，それを回避するため に卵巣に内在する BMP システムが活性化され，PRL 作用を抑制するというフィードバック機構が示され た。また成長ホルモン（GH）の分泌不全状態では, GH および IGF-I 作用の低下により内因性 BMP 活性 が増強する結果, FSH 受容体発現の抑制と顆粒膜細胞 の増殖が光進し，閉鎖卵胞の増加と健常卵胞の減少が 生ずる可能性がある. GH はゴナドトロピンと協調し て卵胞成長を支持するが, 卵巣では IGF-I と BMP 分 子間の拮抗作用を通じて, 卵胞ステロイド分泌の恒常 性が維持されていることが示された。このように，卵 を中心に形成される BMPを介した卵胞細胞間コミュ ニケーションの存在と, 生殖内分泌における BMPの 新たな役割が明らかとなった $。$ 。

\section{下垂体 BMP システムによる内分泌調節と下垂体腫瘍 における意義}

BMP 分子は卵巣機能の調節以外に, 下垂体の発 生・分化においても重要な因子である。ラット下垂体 初代培養を用いた実験により，BMP は下垂体前葉ゴ ナドトロープでの FSH 転写・分泌を促進することが 明らかとなった。さらに，ヒトのゴナドトロピン産生 性下垂体腺腫では, BMP/activinの結合蛋白である follistatin の発現レベルが非機能性腺腫と比べて減弱 していることが確認された。これらの結果から, 内因 性 BMP/activin 作用が発生起源を同じくすると考え られる非機能性腺腫とゴナドトロピン産生腺腫の FSH 産生能の決定付けに関与することが想定された。 また，視床下部では BMP- 2, - 4 が $\mathrm{GnRH}$ ニューロ ンに発現する estrogen receptor (ER) の genome 作 用を減弱して，E 2 による $\mathrm{GnRH} へ$ の負のフィードバ ックを抑制することが示された. BMP 受容体シグナ ル Smad1/5/8は，ER シグナルとクロストークすると いう我々の知見を踏まえ, 下垂体・視床下部の ER と 新たなゴナドトロピン分泌因子 kisspeptin・抑制因子 GnIH の関係に着目して, BMP によるゴナドトロピン 分泌調節機序の解明を目指して研究を進めている ${ }^{2,8}$.

また，下垂体腫瘍の発育・進展のメカニズムと薬物 作用機序との関連を解明して有効な下垂体腫瘍の内科 治療法の開発を目指すべく, 下垂体に内在する種々の
成長因子に着目して基礎研究を行ってきた，術後の残 存腫瘍や下垂体ホルモン産生過剰に対して薬物療法が 選択されるが，クッシング病や薬物反応性にそしい難 治性先端巨大症では腫瘍の増殖抑制と内分泌活性の制 御に苦慮しているのが現状である. GH 産生性下垂体 腺腫（先端巨大症）の薬物治療において, dopamine 作 動薬（DA）および somatostatin 作動薬（SSA）の奏 効性は臨床的に認識されている。しかし一方で, これ らの薬剤を併用した場合に，GH 抑制効果が減弱する 症例があることも知られている。我々は GH 産生下垂 体腫瘍モデルを用いた検討により, DA と SSA の両者 併用による耐性 (GH 抑制効果の減弱) の発生に, BMP4 が関与することを提唱した。つまり下垂体に内在す る BMP-4 は GH 分泌を促進するが, DA はこの BMP-4 作用を抑制する。しかし，高濃度のSSA 存在下では， この DA による BMP-4 抑制効果が減弱する現象を 確認した。さらに，臨床において有効な薬剤がなく問 題となるのが副腎皮質刺激ホルモン（ACTH）を過剩 産生するクッシング病である。我々は，クッシング病 の下垂体腫瘍で発現が減少している $\mathrm{BMP}-4$ が, $\mathrm{ACTH}$ 産生細胞において $\mathrm{ACTH}$ 前駆体遺伝子 POMC の発現を抑制し，ACTH 分泌を制御すること を確認した。そして SSA が BMP-4 受容体 (ALK-3） BMPRII)の発現増加と BMP シグナルの抑制分子であ るSmad6/7の発現抑制を介して, BMP-4による ACTH 抑制を強化することを明らかにした。下垂体腫 瘍の薬物治療において内在する BMP-4 の発現を調 節するという視点からアプローチし, BMP-4を薬物 奏効性の指標として応用したいと考えている ${ }^{8,9)}$.

\section{副腎に発現する BMP-6とアルドステロン分泌への関与}

我々は, 副腎皮質にも機能的 BMP/activin システム が内在することを確認した。アルドステロン産生能を 有するヒト副腎皮質細胞を用いた検討から，副腎皮質 に発現する BMP- 6 がアンジオテンシン II（Ang II） によるアルドステロン産生を刺激し,一方で activin は $\mathrm{ACTH}$ によるアルドステロン産生を促進するという 分泌機序を明らかにした。BMP-6 は副腎皮質におい て, Ang IIにより活性化される MAPK 経路のリン酸 化を促してアルドステロン合成酵素遺伝子 CYP11B2 の転写を誘導し，アルドステロンの産生を増強するこ とを示した。臨床の場ではレニン・アンジオテンシン 系を抑制する降圧薬としてアンジオテンシン変換酵素 
阻害薬（ACEI）やAng II 受容体拮抗薬（ARB）を使 用するが，これらの長期投与により理論上抑制される はずのアルドステロンの抑制効果が減弱して循環レベ ルが再上昇するブレイクスルー現象が生じうる.アル ドステロンは直接的に腎や心血管障害などの臓器障害 を惹起するため, ブレイクスルーを回避したいが，こ の発生メカニズムの詳細は不明であった。アルドステ ロンの主な合成・分泌の調節因子として, Ang II, カ リウム $(\mathrm{K})$ 及び $\mathrm{ACTH}$ が知られているが，さらに副 腎局所に存在する種々の因子によって制御されている と考えられている。我々は, 副腎細胞の培養系で ARB によるブレイクスルーを再現し, BMP- 6 シグナルを 抑制した場合にはこの現象が見られないことから，こ の機序にBMP-6 の作用増強が関与する可能性を提 案した。ラットを用いて内因性 BMP- 6 阻害によるア ルドステロン産生能の変化をin vivo で検証したとこ ろ, BMP-6 - KLH ハプテン投与による BMP-6 抑制 モデルでは, 尿中アルドステロン分泌量の減少と副腎 での CYP11B2発現レベルの低下を認めた。これらの 結果を通じて, 内因性の BMP-6 が副腎皮質における アルドステロンの産生・分泌を促進していることが示 唆された

\section{おわりに}

骨形成蛋白である BMP は, 分化誘導作用における 多機能性から, body morphogenetic protein とも呼ば れる ${ }^{10)}$. BMP は分化の調節のみならず, 分化した組織 においても様々な作用を発揮する。種々の内分泌組織 において, autocrine/paracrine 機序でもたらされる組 織特有の活性は, 臨床応用にも繋がる可能性がある. 例えば，卵巣では卵発育を促進し卵胞閉鎖や閉経を調 節しうる可能性, 女性ホルモンとは異なる避妊薬や骨 粗鬆症治療薬としての創薬の可能性など, BMP を内 分泌調節ツールへと応用できるかもしれない. また下 垂体腫瘍では薬剤応答性の指標として BMP-4に, 副 腎ではアルドステロン分泌能の指標として BMP-6 に着目して研究を展開したい。全身的にBMP システ ムとして捕らえ, 臨床へ応用できる新たなシーズへの 発展に期待して研究を続けたいと考えている（図 2 ).

\section{謝辞}

今回, 岡山医学会雑誌に寄稿させていただく機会を賜りまし た事を，編集長の加藤教授掞よび関係各位の方々へ，心より感

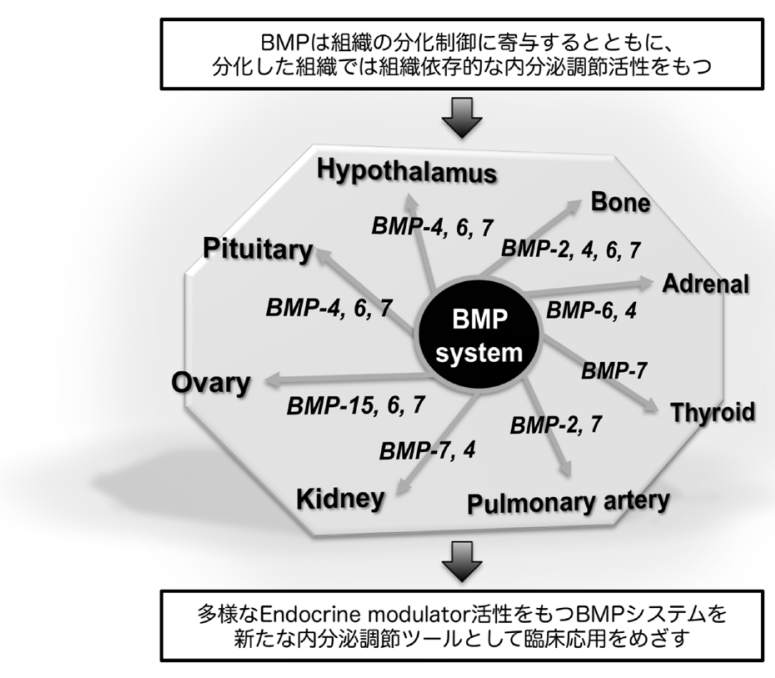

図 2 組織・臟器別に多彩な作用をもつ BMP 分子群

\section{謝申し上げます。}

\section{文献}

1) Shimasaki S, Moore RK, Erickson GF, Otsuka F : The role of bone morphogenetic proteins in ovarian function. Reprod Suppl (2003) 61, 323-337.

2) Shimasaki S, Moore RK, Otsuka F, Erickson GF : The bone morphogenetic protein system in mammalian reproduction. Endocr Rev (2004) 25, 72-101.

3 ) Shimasaki S, Moore RK, Erickson GF, Otsuka F : Ovarian bone morphogenetic proteins in female reproduction. Int Congr Ser (2004) 1266, 241-247.

4) Otani H, Otsuka F, Inagaki K, Suzuki J, Makino H : Roles of bone morphogenetic protein- 6 in aldosterone regulation by adrenocortical cells. Acta Med Okayama (2010) 64, 213-218.

5 ) Otsuka F : Multiple endocrine regulation by bone morphogenetic protein system. Endocr J (2010) 57, 3-14.

6 ) Otsuka F, McTavish KJ, Shimasaki S : Integral role of gdf-9 and bmp-15 in ovarian function. Mol Reprod Dev (2011) $78,9-21$.

7 ) Otsuka F, Inagaki $\mathrm{K}$ : Unique bioactivities of bone morphogenetic proteins in regulation of reproductive endocrine functions. Reprod Med Biol (2011) 10, 131-142.

8 ) Otsuka F, Tsukamoto N, Miyoshi T, Iwasaki Y, Makino $\mathrm{H}: \mathrm{Bmp}$ action in the pituitary: Its possible role in modulating somatostatin sensitivity in pituitary tumor cells. Mol Cell Endocrinol (2012) 349, 105-110.

9) Otsuka F : Multifunctional bone morphogenetic protein system in endocrinology. Acta Med Okayama (2013) 67, 75-86.

10) Wagner DO, Sieber C, Bhushan R, Borgermann JH, Graf D, Knaus P : Bmps: From bone to body morphogenetic proteins. Sci Signal (2010) 3, mrl. 